\title{
Guilty Subjects and Political Responsibility: Arendt, Jaspers and the Resonance of the 'German Question' in Politics of Reconciliation
}

\begin{abstract}
Andrew Schaap ${ }^{1}$
The post-war question of German guilt resonates in contemporary world politics, framing the way actors and observers conceptualize collective responsibility for past wrongs in diverse polities. This article examines the responses of Hannah Arendt and Karl Jaspers to the 'German question': in what sense are ordinary citizens collectively accountable for state crimes and how should they respond to the legacy of past wrongs? Arendt and Jaspers agree on conceiving collective responsibility in terms of a liability predicated on political association that does not impute blame. However, they disagree on the value of the sentiment of guilt in politics. For Jaspers, a spreading consciousness of guilt through public communication leads to purification of the polity. But Arendt rejects guilt in politics, where publicity distorts it into a sentimentality that dulls citizens' responsiveness to the world. These contrasting responses are employed to consider how members of a 'perpetrating community' might be drawn into a politics of reconciliation. I suggest that Arendt's conception of political responsibility, conceived in terms of an ethic of worldliness, opens the way for understanding how 'ordinary citizens' might assume political responsibility for past wrongs while resisting their identification as guilty subjects by a discourse of restorative reconciliation.
\end{abstract}

'YOU ARE GUILTY'. In 1945, these words appeared on posters around towns and cities in occupied Germany as part of the denazification programme instituted by the Allies. Above the words was an image of Buchenwald. Alongside them, an accusing finger pointed at the observer. For many, this was the first confirmation that the death camps really did exist. Consequently, the charge of collective guilt was met with widespread indignation and cynicism (QG, p. 47; Arendt, 1950, pp. 348-9). ${ }^{1}$ How could 'ordinary people' be considered guilty of such terrible crimes? 'We did not know' and 'what could we have done, anyway?' were common defensive responses to the accusation of collective guilt.

The extent to which citizens should acknowledge and assume collective responsibility for grave wrongs perpetrated by their state remains a controversial and pressing political issue in countries such as South Africa and Australia where a political project of 'reconciliation' is presently being promoted. Despite the difficulties inherent in conceptualizing collective responsibility within a liberal moral vocabulary, some kind of collective accounting for past wrongs and responding to the suffering of those wronged is widely perceived as a necessary condition for achieving reconciliation in these societies. In the moment of transition invoked between a violent-

${ }^{1}$ This is a pre-print version of an article published in Political Studies 49(4) 2001: 749-766. Available from: http://www.blackwellsynergy.com/links/doi/10.1111\%2F1467-9248.00340 
repressive past and a peaceful-democratic future, past and future oriented responsibilities of a 'perpetrating community' are conjoined in the declaration 'never again'. In order to underscore a break with the past and secure a future in which such wrongs will not be repeated, what seems to be required is sincere public expression of remorse and widespread personal realization of collective responsibility for past wrongs.

Yet it is clear that citizens who find themselves identified as 'guilty' by this discourse of reconciliation commonly respond, as did many Germans after the war, with either denial or sentimentality. The twofold 'German question' thus resonates in contemporary politics of reconciliation. ${ }^{2}$ In what sense should 'ordinary' members of a 'perpetrating community' acknowledge a share of collective responsibility for wrongs they neither personally committed nor directly supported? To what extent should a collective sense of atonement and remorse animate a politics oriented toward reckoning with the past and making amends with those wronged?

This article compares the responses of Hannah Arendt and Karl Jaspers to the German question and considers the implications of their work for a politics of reconciliation. ${ }^{3}$ A Jasperian account of collective responsibility based on sympathetic identification is closely associated with a restorative conception of political reconciliation in which private and public moralities tend to be conflated. The politics of authentic self-expression that such a conflation leads to threatens an abandonment of political responsibility by guilty subjects. By contrast, Arendt's political ethic of worldliness suggests an agonistic conception of reconciliation, which would enable citizens to assume political responsibility while resisting their identification as guilty subjects.

\section{Accounting for Wrongs: Judging the Past}

Toward the end of the war the Allies began to ask, 'are all Germans collectively responsible for Nazi crimes?' At face value, the responses of Arendt and Jaspers to this question are much the same. They agree that, by virtue of their membership in a political community, all citizens are indeed collectively responsible for reparations to those wronged by their state. This liability, however, does not imply moral blame since such political responsibility is imputable on the basis of association rather than the actions and intentions of each person. In this way, Arendt and Jaspers articulate a distinction between collective guilt and collective responsibility that is now common place (for example Habermas and Michnik, 1994, p. 7). Attribution of collective guilt is unjust because it imputes blame without regard to the actions or intentions of individual group members. Attribution of collective responsibility, on the other hand, is just since it refers only to a liability predicated on the duties of citizenship.

Jaspers differentiates this political responsibility without personal blame (which he misleadingly refers to as political 'guilt') from criminal, moral and metaphysical guilt. He insists that all Germans must accept political responsibility for the crimes of the Nazi state, regardless of their particular involvement. A people must 'answer for its polity' (QG, p. 61). There are several reasons why it is just to hold the German people collectively responsible in this sense. Since members of a polity accrue common benefits by virtue of their association, they are similarly liable for common sanctions 
(QG, p. 40). To the extent that a state institutionalizes common decisionmaking structures, citizens can be collectively held to account for the outcomes of these (QG, p. 60). Moreover, even in the absence of such structures, denizens of a state are in some sense collectively responsible for the 'atmosphere of submission' on which a repressive regime depends to maintain its power $(\mathrm{QG}$,

p. 78). The corollary of this limitation of collective responsibility within the ambit of political guilt is that it is unjust and inhumane to attribute criminal, moral or metaphysical guilt to a 'people'. To do so would be to disregard the heterogeneity of the population and to deny the status of its members as autonomous agents (QG, pp. 40-2).

In differentiating between these four kinds of guilt, Jaspers' principal concern is to facilitate the 'moral and political self-clarification' of his co-nationals (Rabinbach, 1996, p. 20). In particular, he wants to debunk the view that the prosecution of state-criminals and payment of reparations exonerates the population. This leads him to a fairly cursory treatment of political and criminal guilt. These are introduced essentially in order to argue that the Allies' prosecution of war criminals and demands for reparations are not simply an outcome of power politics (i.e. 'victor's justice') but are inherently just. What criminal and political guilt have in common is that they are subject to public judgement. Just as the criminal must answer for his crimes, the people must answer for its polity.

In contrast to criminal and political guilt, however, moral and metaphysical guilt are a matter of individual conscience and are therefore not subject to public jurisdiction (QG, p. 39). Moral guilt might be incurred through conforming with an immoral system out of self interest, showing indifference to the suffering of others, failing to resist a criminal regime, genuflecting to its values while knowing them to be immoral, giving tacit support to a regime, trying to see something 'good' in it, or deceiving oneself that one could change the system from within (QG, pp. 63-70). Metaphysical guilt, on the other hand, is incurred through a failure to show 'absolute solidarity' (i.e. Christ-like love) to one's fellow human beings, irrespective of one's particular relation to them (QG, p. 32). While moral and metaphysical guilt are not collectively imputable in the sense of political guilt, the implication of Jaspers' analysis is that all Germans are morally and metaphysically guilty, to varying degree, by virtue of their individual actions and inactions during the Nazi regime.

That Germans are collectively liable is taken for granted by Jaspers. The pertinent question, for him, is 'in what sense each of us must feel coresponsible' (QG, p. 61, emphasis added). Publicly, 'purification' of the German polity depends on state reparations and punishment of war criminals. But the deeper process of purification that Jaspers advocates depends on the realization of moral and metaphysical guilt by ordinary Germans in communication with one another. Just as the realization of moral guilt brings insight, which involves 'penance and renewal' and leads to 'inner development', so recognition of metaphysical guilt leads to 'transformation of human self-consciousness before God' (QG, p. 36). The spreading consciousness of individuals of their personal implication in Nazi crimes will lead to a widening and deepening sense of co-responsibility and, consequently, to a transformation of the "collective morality contained in the 
ways of life and feeling' of the German polity (QG, p. 79).

Jaspers differentiates German guilt, then, both to facilitate the realization of individuals of their co-responsibility for Nazi crimes and to define the limit of public judgement. Jaspers' distinction between political/criminal guilt and moral/metaphysical guilt is predicated on the liberal distinction between public and private in that it circumscribes a private sphere of personal (moral and metaphysical) accountability that is not subject to public scrutiny. This is an important limit to set if we are to protect individual citizens from unjust punitive state measures (for example witch-hunts). However, as Rabinbach (1996, p. 21) points out, it leads to a somewhat thin account of political responsibility in Jaspers' analysis. To be sure, Jaspers emphasizes the importance of public communication between particular individuals for coming to a realization of moral and metaphysical guilt and, hence, a sense of co-responsibility. Yet this remains a fundamentally personal process of selfrealization. Aside from the general obligation to make reparations, Jaspers hardly considers how this co-responsibility might be assumed politically.

By contrast, Arendt provides a more robust conception of political responsibility. ${ }^{4}$ Like Jaspers, Arendt (1987, pp. 43-6) insists on a clear distinction between collective responsibility (which is always political), and personal responsibility (which is legal or moral). Political responsibility is distinct from personal responsibility in that it is vicarious and involuntary. It is vicarious because a citizen may be held liable for things he or she did not do and it is involuntary because it results from his or her (typically not chosen) membership in a political community. Although individuals may be held liable for acts that are involuntary and vicarious, they can not be held to blame. While liability is transferable between moral agents, blame is not. Since guilt always involves blame it is morally incoherent when applied collectively.

While following the same line of reasoning as Jaspers in defining this limit, Arendt emphasizes the obverse of his moral point. She emphasizes not so much that the imputation of collective guilt unjustly disregards the possible innocence of particular individuals than that it diverts attention from the particular culpability of individuals. The identification of a collectivity as guilty of wrongs obscures the fact that such wrongs are only possible through the particular actions (and inactions) of individuals. As Arendt often puts it, 'where all are guilty none is' (Arendt, 1987,

p. 43, 1964, p. 185; JP, p. 230; EJ, p. 278; CR, p. 162). The abstractness and generality of a theory of collective guilt has the effect of making judgement of particular acts and events superfluous. To confess collective guilt is 'devoid of all risk' since it attempts to account for every event and deed in a single pronouncement. Collective blame suggests the inevitability of events, retrospectively removing outcomes in human affairs from the influence of individual action (EJ, p. 297). Acknowledgement of collective guilt, then, actually amounts to a plea of personal and political irresponsibility.

This is especially pernicious for Arendt, since it was precisely a widespread abdication of moral and political responsibility that made the death camps possible. This was manifest both in an unwillingness to judge and a widespread personal feeling of being superfluous (OT, pp. 311ff.; EJ, p. 114; Arendt, 1964, p. 205). Arendt singles out bureaucracy and ideology as modern inventions that relieve individuals of political responsibility. Bureaucracy does 
so by evaluating individual actions according to their efficiency in performing a function rather than on the basis of the ends they seek to realize. Individuals are discouraged from evaluating these ends since they lack the expert knowledge deemed necessary to properly do so (OT, p. 214). In this way, bureaucracy leads to 'rule by nobody' (HC, p. 40; EJ, p. 289). Similarly, ideologies relieve individuals of the capacity to judge by attributing all outcomes in human affairs to processes such as nature or history, which are perceived as beyond the influence of spontaneous human action. Individuals are required to submit to a 'tyranny of logicality' that rejects as anomalous all experience contradictory to an internally coherent system of thought (OT, p. 465).

Facilitated by bureaucracy and ideology, abdication of political responsibility enabled 'normal' individuals like Adolf Eichmann to become functionaries in the Nazi regime (EJ, p. 276; Arendt 1971b, pp. 498-500). Good family men were able to perform their murderous duties efficiently and without comprehending the gravity of their wrongdoing since they perpetrated crimes in their professional capacity and not out of personal inclination. Because they related to the public sphere primarily as a means to secure their private happiness by providing for their families, they failed to draw a connection between their private and public selves. In their public roles they acted according to the values of the job holder (security and efficiency) rather than the values of the citizen (judging and acting for the sake of the world one shares in common with others) (JP, pp. 231-4). Since they were unable to transcend the subjectivity of their private lives, they failed to recognize the evil of their deeds, their impact on the world (HC, p. 57; Arendt 1964, p. 205; EJ, pp. 25ff.).

Importantly, the political irresponsibility that made the crimes of the Nazis possible is not peculiar to Germany but is an 'international modern phenomenon' (JP, p. 233). Abdication of political responsibility is symptomatic of the modern condition of 'world-alienation' (HC, pp. 208ff., 248-57). World, for Arendt, is distinct from the natural environment humans inhabit, the Earth. A world is an artificial realm of things created through work. This human artifice provides a durable space in which members of a polity can appear to one another. A world also includes those human affairs that go on within this durable space of things, the intersubjective web of human relations that overlays the objective world. A world gives permanence and meaning to human affairs by providing a space of remembrance that outlasts the natural lives of its particular members. The world is held in common, therefore, not only by those presently in it but with those who came before and those who will come after (HC, pp. 52 ff.). World-alienation arises when members of a polity cease to value political action - the sharing of public speech and deeds

- as the activity through which the common reality of this world is disclosed. Instead, political life comes to be understood in terms of either a means to some end (instrumental rationality) or, worse, the public organization of private needs satisfaction (hedonistic utilitarianism) (HC, p. 208).

Arendt formulates her understanding of political responsibility, then, in opposition to the anti-politics of totalitarianism (Canovan, 1992, pp. 275-6). The model citizen of the totalitarian state is the concentration camp inmate, reduced to total obedience, living in utter isolation without individual identity 
or a sense of reality in common with others (OT, p. 456). By contrast, Arendt's ideal citizen publicly engages with diverse others to disclose a common reality from a plurality of perspectives, to disclose her unique identity through public speech and action and to accord dignity to other citizens through mutual recognition of each other as members of a common world (MDT, pp. 3-11, 23-31). The object of political responsibility is therefore the world one shares in common with others. Through acting and speaking for the sake of this world, its commonness is disclosed (HC, pp. 50-8).

In this context, acknowledgement of collective guilt appears unpolitical. Rather than disclosing the commonness of the past in its diversity, it reduces our understanding of the world under a single perspective. Theories that impute guilt to a collective render irrelevant the particular perspectives (the 'it-seemsto-me') of individuals, leaving them unresponsive to the claims of the world. By contrast, political responsibility makes a claim on the individual for 'an ongoing responsiveness to the world, including a need to respond for what has been done' (Williams, 1998, p. 946). This means, above all, forming and publicly disclosing opinions, judging the significance and meaning of particular actions and events (JP, p. 248). While Arendt doubts that an evil past can be 'mastered', she argues that it is possible to 'reconcile ourselves to it', to accept the fact that an event as terrible as the Holocaust could be brought into the world (MDT, p. 19). Political responsibility enjoins us, for the sake of this world, to acknowledge what happened and to seek to understand the significance of past events for our life in common.

\section{Responding Politically: Acting for the Future}

While the first government of the Federal Republic of Germany certainly accepted a liability for reparations, it is commonly argued that Germans tended to 'instrumentalize' the issue of collective responsibility (for example Rabinbach and Zipes, 1986, p. 5). Through reparations, the new state sought to settle accounts once and for all with those persecuted by the Nazi regime, to forget the past and move on. Moreover, it is argued, the reluctance of Chancellor Adenauer to acknowledge collective guilt for Nazi crimes reflected a general inability of most Germans in the post-war era to understand their implication in what had happened (Olick and Daniel, 1997, p. 928). While political liability was generally accepted, there was a failure to accept moral guilt by the majority of Germans (Reuter, 1990, pp. 174-5).

According to some commentators, Jaspers' influential book contributed to this cultural milieu because it drew an overly clear distinction between morality and politics as autonomous spheres of responsibility and situated the burden of coming to terms with the past squarely in the moral sphere of individuals. Rabinbach (1996, pp. 23-4) argues that this legitimized the government's emphasis on reparations and official declarations of responsibility in place of what could have been more effective and meaningful political attempts to acknowledge the truth of the Nazi past. Similarly, Barnouw (1990, p. 159) insists, it resulted in the displacement of a collective reckoning with the past to the private sphere, where it became a psychological issue of personal healing rather than a properly political concern.

These objections, though, are difficult to reconcile with Arendt's description 
of Jaspers as one of those rare philosophers who unequivocally affirms the public realm and who possesses a 'political mentality par excellence' (MDT, pp. 74, 79). Rabinbach and Barnouw's criticisms seem to elide what Rabinbach (1996, p. 20) himself recognizes as Jaspers' over-riding theme, 'the renewal of a German polity through communication'. Given Jaspers' (QG, p. 23) Kantian insistence on the importance of publicity and communication for a healthy political life, his alleged contribution to the socalled 'silent' coming to terms with the past in the immediate post-war years seems unlikely.

If Jaspers' text did contribute to the apparent failure in post-war Germany to openly and genuinely reckon with the past, this was not due to an overly rigid distinction between morality and politics. As we have seen, Jaspers does differentiate moral guilt from political responsibility in order to determine the limits of public judgement. However, he does not understand morality and politics as autonomous spheres, requiring distinct and potentially contradictory norms of human interaction. On the contrary, he insists that 'there can be no radical separation of moral and political guilt' (QG, p. 77). Jaspers emphasizes the dialogic relation of the moral self and the political community to which it belongs (QG, pp. 33-4). The ethos of a political community arises from the 'moral everyday life of individuals' and the morality of individuals is, in turn, formed by the ethos of a political community. While moral guilt is strictly personal, there is nevertheless a 'collective morality contained in the ways of life and feeling, from which no individual can altogether escape and which have political significance as well' (QG, pp. 78-9). Indeed, this collective morality emerges as prior to the political, in Jaspers' account, since it enables and sustains political freedom.

There is no radical separation, then, but a conflation of moral and political norms in The Question of German Guilt. This is apparent in the theological vocabulary of guilt, atonement, purification and grace in which Jaspers discusses the realization of political freedom and democracy in Germany (Rabinbach, 1996, p. 16). For Jaspers, 'without purification of the soul, there is no political liberty' (QG, p. 121). While moral guilt can not be judged from without, when felt from within it institutes 'an inner upheaval which seeks to realize political liberty' (QG, p. 77). In this way, the spreading consciousness of moral guilt leads to the transformation of the moral-political community.

Having insisted initially on a clear differentiation of moral and political guilt, Jaspers proceeds to temper this distinction in order to trace the relation between the sentiment of guilt and the realization of political freedom. Individuals need not, after all, be directly implicated in particular wrongs in order to experience an 'inner upheaval'. Through sympathetic identification, based on a common culture, individuals may appropriately feel co-responsible for wrongs they neither directly perpetrated nor supported. For Jaspers:

... the fact of my being German - that is, essentially, of life in the mother tongue - is so emphatic that in a way which is rationally not conceivable, which is even rationally refutable, I feel co-responsible for what Germans do and have done. (QG, p. 80)

Jaspers likens this feeling of co-responsibility to that which we feel for the deeds and misdeeds of family members. 
This notion of co-responsibility based on a common culture is given a peculiar twist insofar as Jaspers articulates the foundation of a post-war German identity in terms of the realization of a universal citizenship predicated on the ruins of a shared tradition. For Jaspers, the destruction of Germany means that he is able to feel 'for the first time uninhibited as a German' (quoted in Rabinbach, 1996, p. 22). The ruin of Germany frees the individual for selffashioning. As Rabinbach (1996,

p. 17) astutely observes, Jaspers' text revolves around the motif of 'transposition' between Germans and Jews: Germans changing from a nation-state to a cosmopolitan citizenry and Jews from cosmopolitan statelessness to a sovereign people. Anticipating Habermas' advocacy of 'constitutional patriotism', Jaspers embraces Germany's pariah status, the loss of sovereignty and lack of national cohesion as an opportunity for moral and political reinvention. Acceptance of guilt should become a 'fundamental trait of ... German self-consciousness' (QG, p. 119). In this way, the question of guilt is central to the post-war 'self-image and ideal of a nationless and cosmopolitan Germany' (Rabinbach, 1996, p. 17). Guilt leads to the realization of political freedom, since it underwrites the affirmation of Western political values of democracy and individual autonomy.

Arendt is similarly concerned that ordinary Germans should come to a realization of their personal implication in the crimes of the Nazi state. On a return visit to Germany in 1950 , Arendt $(1950$, p. 342) was appalled by what she describes as 'a deep-rooted, stubborn, and at times vicious refusal to face and come to terms with what really happened' among the populace. However, in contrast to Jaspers, she finds the sentiment of guilt detrimental to the realization of political freedom (Arendt, 1987, pp. 43-4). This is particularly evident in her contemptuous criticism, over a decade later, of the radical student movement in Germany. ${ }^{6}$ Arendt writes:

Those young men and women who every once in a while ... treat us to hysterical outbreaks of guilt feelings are not staggering under the burden of the past, their fathers' guilt; rather they are trying to escape from the pressure of very present and actual problems into a cheap sentimentality (EJ, p. 251).

To Arendt, such vicarious guilt is self-indulgent and self-gratifying. Given that, in the sixties, many of those who are actually guilty while feeling no such remorse retain positions in public office, the proper affective response to the situation is indignation, not guilt. This next generation of Germans should initiate worldly change, not indulge in public lamentation.

Arendt's objection to this kind of politics is informed by her recognition that collective guilt obfuscates individual culpability, as already discussed. However, it is also due to the clear distinction Arendt (1987, pp. 46-50) draws between private and public, and between the moral and the political. For Arendt, those conditions peculiar to public life - plurality, appearance, frailty, contingency - require that we derive a set of norms appropriate to this sphere of human interaction in contradistinction to the private sphere (HC, pp. 2378). Standards of human conduct appropriate to the private realm may not be appropriate to and may, in fact, be destructive of the public realm. As already mentioned, the standards of instrumental rationality and hedonistic utilitarianism undermine the meaning-constitutive aspect of political action, the 
sharing of public words and deeds. However, actions and judgements motivated by moral concerns may also be inappropriate to the public sphere, since they do not necessarily take account of, and may necessarily preclude, consideration of the particular claims of the world. For Arendt, as Canovan (1992, p. 185) puts it, "personal morality cannot solve the dilemmas that arise out of the very nature of politics itself'.

Arendt's distinction between the moral and the political hinges on her claim that 'in the centre of moral considerations of human conduct stands the self', while 'in the centre of political considerations of conduct stands the world' (Arendt, 1987,

p. 47). Moral considerations are self-regarding insofar as they are guided by the kind of person one is or wants to be. By contrast, political considerations are not so much concerned with whether one is good as whether one's actions are good for the world in which one lives. ${ }^{7}$ For the good man it is 'better to suffer wrong than to do wrong' because it is 'better for me to be at odds with the whole world than, being one, to be at odds with myself' (Arendt, 1987, p. 47; see also CR, pp. 58-68; TMC, pp. 438-446). The good man's actions are fundamentally subjective and self-regarding, since he values this togetherness of the self over togetherness with others. By contrast, the good citizen places his city higher than his soul. He cares more for the world than for his self. From the perspective of the world, the 'states of mind of those involved' in a wrong, the sufferer and the doer, are of little relevance (CR, p. 63). What matters is that a wrong has been done in the world. The citizen is called on not simply to avoid wrongdoing but to act in order to sustain a world in common, that is, to prevent wrongdoing and to set the world right when it has been wronged.

Authentic political action and judgement, then, require us to act and judge for the sake of the world rather than the self. But moral sentiments, since they originate in a conscience which 'trembles for the self and its integrity' (CR, p. 61), denature political action and speech by dulling an individual's responsiveness to the world. Like the virtuous sentiments of love, goodness, conscience, compassion and pity identified by Kateb (1984, pp. 25-9), guilt becomes a vice in politics. While the sentiment of guilt may be proper to immediate relations between particular persons outside the glare of the public sphere, publicity distorts guilt into a sentimentality that undermines genuine political engagement.

Several pernicious consequences arise from the conflation of the moral and the political in a sentimental politics of guilt. First, like love, guilt based on sympathetic identification threatens the in-between space of the public sphere, by predicating association on a natural bond rather than the artificial conventions and institutions of the world (Arendt, 1987, pp. 43-4; MDT, pp. 13ff.). It thus abolishes the distance between actors that is required in order to permit the manifestation of difference and disagreement and to prevent these from leading to violence. Second, guilt introduces an absolute standard into the political realm, which is inherently relative. All moral truths become 'mere' opinion when introduced into the public sphere. By virtue of being a sentiment, guilt (like compassion) can be 'enjoyed for its own sake' and this can quickly 'lead to a glorification of its cause' (OR, p. 89; EJ, p. 251). A moralistic politics of guilt is, therefore, likely to turn away from the worldly activities of persuasion and compromise in order to assert the absolute validity 
of its moral truth (OR, pp. 86-7).

Third, guilt is not generalizable, since it properly only concerns particular others. In order to be fit for 'public appearance', however, words and acts must be 'transformed, deprivatized and deindividualized' (HC, p. 50). When publicly expressed in relation to a whole category of people, then, guilt fails to comprehend these wronged others in their singularity (OR, p. 85). Fourth, guilt is mute, whereas political action must be articulate. Like compassion, guilt is revealed through gestures and expressions of countenance. When guilt is publicly eloquent its sincerity becomes questionable (OR, p. 85; HC, p. 73). Remorse often rings true in the confession box, rarely from the soapbox. Finally, guilt is self-expressive, whereas politics is performative. In order to demonstrate its authenticity, guilt must prove its sincerity. However, sincerity is an inappropriate criterion of judgement in politics, where what counts is not the intentions or motives of actors, but the actual performance of words and deeds themselves insofar as these illuminate the meaning of a life in common (HC, pp. 205-6). When sincerity becomes the rule in public life, this is likely to lead to a disastrous politics that seeks to 'unmask' the hypocrisy of actors (OR, pp. 98-109; see Villa, 1999, pp. 137-41).

While insisting that guilt and moral sentiments in general are antipolitical, Arendt does not advocate a rationalistic, emotionless politics (CR, pp. 160ff.). Indeed, an inability to be moved is as deleterious as sentimentality in politics (Arendt, 1950,

p. 342). Rather, political action should be motivated by a 'passionate openness to the world and love of it' (MDT, p. 6). Since the political always concerns the world we share in common, authentic action and judgement always draws the person beyond the concerns of the self (HC, p. 65). Indeed, as Kateb (1984, p. 12) notes, this is the 'most profound existential achievement of action'. The freedom experienced in political life is that of transcending one's subjectivity in order to constitute and affirm an intersubjective reality through partaking in an incessant discourse about the ends of living together in the world, the basis on which the polity is constituted (Villa, 1995, p. 35). Political action, therefore, should not be driven by selfregarding motives such as guilt. Rather political action should be 'inspired ... from without' by a principle. Unlike individual motives, the 'validity of a principle is universal, it is not bound to any particular person or any particular group' (BPF,

p. 152). To act from a principle is thus to act in a depersonalized way (see Williams, 1998, pp. 942-6).

Guilt, like other self-regarding sentiments, limits a person's capacity to respond politically; that is, to think representatively, to imagine the world from a plurality of perspectives and to judge and act based on a particular opinion that claims intersubjective validity. Guilty subjects make poor citizens insofar as they remain 'imprisoned in the subjectivity of their own singular experience' (HC, p. 58). Importantly, as in the case of collective guilt, this 'does not cease to be singular if the same experience is multiplied innumerable times' (HC, p. 58). Instead of signalling political engagement, then, a politics of guilt constitutes a 'flight ... from the world into the self', an abandonment of political responsibility (HC, p. 6). 


\section{Authenticity and the Agon in Politics of Reconciliation}

We have seen that while Arendt and Jaspers reach similar conclusions about the extent to which citizens should collectively answer for past wrongs, they differ over how citizens should respond politically to ameliorate a legacy of wrongdoing. Arendt and Jaspers agree that collective accountability for state wrongs should be conceived in terms of a political responsibility that does not imply blame. Yet both of them also consider that a proper reckoning with past wrongs involves considerably more than accepting a duty to make reparations. Citizens have a further responsibility to understand and acknowledge what happened and it is in accounting for how such an understanding might be reached that Jaspers and Arendt diverge. Whereas Jaspers envisions this understanding as coming about through sincere communication among intimates concerned for each other's souls, Arendt's political theory suggests that such understanding can be only tentatively achieved through acting and judging for the sake of the world. While Jaspers perceives the experience of guilt as necessary for coming to terms with the past, Arendt fears that guilt prevents actors from transcending their own motives and self-regardingness when engaging with each other in public speech and action. These contrasting positions offer alternative ways of considering the comportment with which members of a 'perpetrating community' should enter into a politics of reconciliation.

Like the denazification posters in occupied Germany, the discourse of reconciliation interpellates subjects as guilty by virtue of their membership in a perpetrating community. In polities reckoning with past wrongs, such as Australia and South Africa, a state-instituted discourse of reconciliation provides a vocabulary in which citizens imagine and debate the terms of their political association. 'Ordinary' citizens are called upon to acknowledge past wrongs and their implication in these as, for instance, tacit supporters or beneficiaries. Collective acknowledgement of and reparation for wrongs is understood to clear the way for the establishment a new dispensation of civic friendship and mutual respect between groups.

The apparent incongruity between post-war Germany (in which few Jews remained) and contemporary contexts such as South Africa (in which 'perpetrating' and 'victimized' communities must coexist) might raise doubts about the relevance of Jaspers' and Arendt's considerations of the German question for thinking about reconciliation. An understanding of collective responsibility as predicated on membership in a polity suggests, for instance, that following a transition to democracy all citizens of the state must assume responsibility for the actions of the former regime. ${ }^{8}$ Yet this seems to offer little guidance as to how the collective responsibility of a perpetrating community within a divided polity might be mobilized. A citizenship-based conception of political responsibility does, though, allow the differentiation of a particular collective responsibility of a group within a polity in whose interest a former regime presumed to act. We can insist on a particular responsibility of all those belonging to a particular category of persons who enjoyed citizenship or benefits under a regime which instigated wrongs against those who were either denied citizenship or treated as second-class citizens. A difficulty arises, however, as to how this collective responsibility might be mobilized politically, given that under a successor regime the perpetrating community lacks (or should lack) political institutions that are 
exclusively its own.

How, then, might subjects identified as guilty by a discourse of reconciliation realize their particular political responsibility within a polity divided by past wrongs? Experience suggests that ordinary citizens tend to respond to their interpellation as guilty subjects with either denial or inertia. Krog (1998, pp. 162-3) observes that in South Africa those whites who responded with denial questioned the impartiality and evidential standards of the Truth and Reconciliation Commission (TRC), claimed that they did not know what was going on at the time and/or attributed those wrongs that were perpetrated to 'a few bad apples'. On the other hand, many whites were, in fact, 'deeply involved and moved' by the work of the TRC. They followed the publicly broadcast proceedings keenly, they sent letters of support to the commission, formed study groups and so on. But at the same time as they recognized their implication in past wrongs, they felt "powerless to deal with the enormity of the situation'.

In Australia, a similar division among non-indigenous Australians has been manifest in the dispute over Prime Minister Howard's refusal to apologize to indigenous Australians for state wrongs perpetrated against them. Howard (2000, p. 90) has expressed 'deep personal sorrow' for injustices perpetrated by 'past [sic] generations'. However, he has insisted that 'Australians of this generation should not be required to accept guilt and blame for past actions and policies over which they had no control'. In taking this position, he appealed to the sensibility of the 'silent majority' of white Australians. Yet, many non-indigenous Australians publicly expressed their sense of coresponsibility for past wrongs through signing 'sorry books', participating in mass marches organized on an unofficially declared 'sorry day' and through other forms of symbolic political communication. While these forms of action have provided an important opportunity for citizens to express their support for reconciliation, this has also been accompanied by inertia. Many citizens have felt unsure how to translate this popular expression of good will into a more tangible and meaningful reconciliatory politics.

The common responses of either denial or inertia by guilty subjects result to some extent, I think, from conflating moral and political modes of conduct. This leads individuals to respond with denial to what is perceived as an unjust attribution of blame or else, in accepting a personal sense of implication in past wrongs, to be overwhelmed by a limitless sense of responsibility. Arendt's understanding of collective responsibility suggests a way of responding that avoids these alternatives. It suggests a way of accepting a particular political responsibility while resisting interpellation as guilty subject. Below, I begin to draw out the implications of an Arendtian politics for thinking about reconciliation by sketching an agonistic conception of reconciliation. This is contrasted against a Jasperian restorative conception of reconciliation in terms of their respective animating principles, orientations and criteria for judging public speech-acts.

\section{Principle: Sympathetic Identification versus Worldliness}

The animating principle that draws guilty subjects into a reconciliatory politics, in a Jasperian sense, is sympathetic identification. By virtue of a common identity, individuals feel a sense of co-responsibility or shame that leads them 
to act politically in order to ameliorate past wrongs. However, the high degree of solidarity that is required within a group in order to engender shame among its members tends to both occlude differences within a group and to exclude different others. In situations of reconciliation this is especially problematic since it is likely to mute a potentially enlightening conflict of opinion over the significance of past wrongs. Moreover, those who do not accept an identification that entails shame might withdraw from a process of reconciliation altogether. Yet it is precisely those people who deny responsibility for past wrongs that it is, perhaps, most important to draw into such a process. The principle of sympathetic identification can lead, in this way, to the kind of impasse between inertia and denial described above. In order to proceed, restorative reconciliation requires acknowledgement of responsibility for past wrongs from guilty subjects. Yet, at the same time, it is precisely this precondition for participation that prevents many from being drawn into the process.

Arendt's principle of worldliness, by contrast, suggests a way of conceptualizing an agonistic reconciliation that frees members of a perpetrating community to assume political responsibility while resisting the identity through which they are implicated in past wrongs. Agonistic reconciliation does not require remorse as a precondition for participation but makes possible a shift in understanding or an 'aspect change' (Norval, 1999, p. 500) as an eventuality of participation. Citizens are drawn into a reconciliatory politics by a care for the world they share in common with others. Assuming political responsibility, in this sense, requires a 'vigilant partiality', a 'taking sides for the world's sake' (MDT, pp. 29, 7-8). Worldliness leads to agonism in politics since it is in disclosing judgements of worth through public words and deeds that actors seek to distinguish themselves. While such judgements are contingent on an actor's particular perspective in the world, at the same time their validity significantly depends on their persuasiveness. In judging and acting for the sake of the world, participants in an agonistic reconciliation are forced to form and articulate opinions in such a way that lures them beyond concerns of the self. While an actor's perspective will no doubt depend, to some extent, on a group identity formed in relation to existing divisions within a polity, its validity depends upon an actor's capacity to transcend motivations of guilt and identification.

A plausible objection to the exclusion of guilt from politics that the principle of worldliness entails is that in doing so we deprive politics of the energy moral sentiments bring (for example see Kateb 1984, p. 29). Without a sense of shame based on sympathetic identification, for instance, there might not have been the high turn out for marches in support of reconciliation in Australia. However, such moral energy is unlikely to lead to reconciliation unless the subjective responses of guilty citizens undergo a worldly transformation that makes them fit for public appearance. Without this kind of transformation, guilty subjects lapse into a sentimentality that continues to marginalize those wronged others with whom they should politically engage.

\section{Orientation: Restoration versus Constitution}

Following Jaspers, the orientation of reconciliatory communication is restoration. Through repentance, guilty subjects seek to reaffirm those shared 
norms that were violated by past wrongs. Public acknowledgement of guilt makes 'social healing' possible (Humphrey, 2000, p. 15). Through a purifying process of remorse, repentance and reparation a 'broken moral order' is restored (Zalaquett in Boraine and Levy, 1995, p. 46; Villa-Vicencio, 1996, p. 132). This restorative orientation resonates with our moral intuitions. As Morris (1976, pp. 93, 96) points out, guilt is not entirely self-regarding. The pain of guilt demonstrates care for the other and for a relationship that has been violated through wrongdoing. At the centre of guilt is the "need to make amends, to mend what has been damaged and to be at one with others [as well as] oneself' (Morris, 1976, p. 100). In this way, guilt demonstrates a desire for a coming together again, the initiation of a 'rite of passage back to union' (Morris, 1976, p. 96).

However, the application of this moral grammar of guilt to polities divided by past wrongs is paradoxical. A discourse of reconciliation tends to rely on a metaphor of 'return' to an original condition of harmonious relations (for example see Moon, 2000). Wrongs of the past are imagined to have violated these relations, tearing apart the social body and resulting in a 'traumatized, divided, wounded, polarized people' (Tutu in Ignatieff, 1996, p. 111). A process of Jasperian 'purification' is followed in order to bring social healing to a body politic made sick by grievous wrongs. But, as Christodoulidis (2000, pp. 190-6) points out, this narrative of restoration makes an 'unwarranted invocation' of a 'we'. According to the logic of guilt, wrongdoing alienates the wrong doer from the moral community. Remorse and repentance indicate a desire to restore what has been damaged. Yet, in most instances in which political reconciliation is sought, "there is nothing to go back to' (Krog, 1998,

p. 109). Wrongs perpetrated against particular categories of people were predicated on their exclusion from the moral community. The restorative conception of reconciliation therefore makes a presumption of what in fact it must achieve.

Agonistic reconciliation is oriented toward constitution rather than restoration in that it seeks not to restore an imagined moral order that has been violated but to initiate new relations between members of a polity (MDT, p. 11). Agonistic reconciliation does not concern harmonizing pre-existing moral identities. Rather, it involves 'calling something into being which did not exist before', that is, constituting the ends of the new political community through spontaneously responding to the world (BPF, p. 151). A reconciliatory moment is not construed as a final shared understanding or convergence of world views, but as a disclosure of a world in common from diverse and possibly irreconcilable perspectives. This disclosure is a momentary and contingent achievement that must be continually resought through partaking in the public business of judging, arguing and persuading over the significance of public events.

\section{Judgement: Authenticity versus Virtuosity}

The success of Jasperian reconciliatory communication depends upon its judgement as authentic. In the absence of sincerity, apology appears worthless to a wronged party. To be persuaded that forgiveness is appropriate, those who have been wronged must be convinced that the remorseful subject has 
suffered the pain of guilt, which comes from violating what one values (Bhargava, 2000, p. 67). While the standard of authentic self-expression might be appropriate to intimate relations, however, it tends to have a destructive impact on the public sphere. This has been evident in Germany, for instance, where there is considerable pressure for political actors to adopt an appropriate attitude of atonement when speaking of the Nazi past. Buruma (1995, pp. 21-2) explains that politicians must show that they are betroffen when discussing past events. To be betroffen suggests a subjective state of guilt, shame, embarrassment, speechlessness and contriteness. However, a public expectation of such sincere expression means that utterances about the past become vulnerable to being questioned according to the true understanding of the actor, which is veiled by his or her words. The demand for sincerity shifts the emphasis of political life away from contesting and debating the significance of past events, to conforming to a ritualistic mode of behaviour that is intended to convey that actors have properly 'come to terms with the past'.

By contrast the criterion for judgement of the Arendtian actor is not sincerity of expression but virtuosity of performance (BPF, p. 153). What counts is not so much the intentions or motivations of actors, but the significance of the speech or deed itself insofar as it illuminates the common affairs of the polity. Virtuous action leads citizens to a closer understanding of their life in common. Recognition of this performative aspect of politics is necessary in order to maintain a space in which actors are free to respond spontaneously to the world. The rejection of sincerity as a proper criteria for public life frees citizens to initiate unprecedented acts and to articulate opinions that may be illuminating because they go against the grain of conventional understanding. Action is depersonalized since citizens assume a civic persona through which the truth in their opinion can sound. Moreover, the capacity of individuals to distinguish their civic roles from private concerns is necessary in order to make possible the sharing of words and deeds in public between members of groups used to identifying each other in radical opposition. Judging action in terms of the virtuosity of performance depersonalizes political conflict and thus guards against it leading to violence or domination predicated on a friend/enemy relation.

Arendt reminds us that we should frame our moral aspirations for our life in common in relation to the condition of plurality that is peculiar to political interaction. I have suggested that a Jasperian politics of reckoning with the past animated by sympathetic identification, oriented to restoration and judged according to authenticity underpins a restorative conception of reconciliation. The problem with thinking of reconciliation in these terms is that reconciliation can not proceed until guilty subjects recognize themselves within the terms in which they are identified by the discourse of reconciliation. Against this conception I have sketched an Arendtinspired agonistic reconciliatory politics that would be animated by worldliness, oriented to constitution and judged according to virtuosity. Conceptualizing reconciliation in these terms, opens the way for understanding how 'ordinary citizens' might assume political responsibility for past wrongs while resisting identification as guilty subjects. Such responsibility entails that citizens engage in a depersonalized but conflictual politics. Participants to such a process may not arrive at a shared understanding of the past. While the outcome of an agonistic 
reconciliation can not be predetermined nor foreseen, a common sense of a shared reality ought to emerge out of the multiple and, perhaps, irreconcilable perspectives of a diverse polity. For the sake of the world in which wrongs were perpetrated, political responsibility enjoins us, in this sense, to 'know precisely what was, and to endure this knowledge, and then to wait and see what comes of knowing and enduring' (MDT, p. 20).

\section{Notes}

Earlier versions of this article were presented at the Northern Political Theory Association conference at the University of St Andrews in September 1999 and at the Political Studies Association conference at the LSE in April 2000. Thanks to Keith Breen, Emilios Christodoulidis, Allyn Fives, Kimberly Hutchings, Hilary Lawson, Claire Moon and the reviewers for their detailed comments.

1 When citing Jaspers' text, The Question of German Guilt, the abbreviation QG is used. When citing Arendt's major texts, the following conventions are used: BPF - Between Past and Future; CR - Crises of the Republic; EJ Eichmann in Jerusalem; EU - Essays in Understanding; HC - The Human Condition; JP - The Jew as Pariah; MDT - Men in Dark Times; OR - On Revolution; OT - The Origins of Totalitarianism; TMC

- 'Thinking and Moral Considerations'. Other works by Arendt are cited using the standard Harvard system.

2 A recent edited collection on political apology begins with a section on 'Nazi persecution' (Brooks, 1999). Duvenage (1999), Schwan (1998) and Gaita (2000) draw comparisons between the post-war German experience of 'coming to terms with the past' and contemporary political situations in South Africa, East Germany and Australia respectively. Moreover, Karl Jaspers' The Question of German Guilt continues to be read and referred to in relation to contemporary contexts by policy-makers and academic observers. For instance, see Kritz (1995) in which Jaspers' text is excerpted. See also: Villa-Vicencio (1996, pp. 133ff., 2000, p. 68); and Krog (1998, pp. 97, 164).

3 This comparison is of scholarly interest given Arendt's personal and intellectual relationship to Jaspers. Arendt was Jaspers' doctoral student at Heidelberg in the late $1920 \mathrm{~s}$, before she was forced to flee Germany as a Jewish refugee. After the war Jaspers and Arendt established a life long correspondence through which they discussed each other's work (YoungBruehl, 1982, p. 215). One of the few texts Jaspers cites in his Question of German Guilt is an early [1945] essay by Arendt (in JP, pp. 225-39). Moreover, soon after Jaspers completed his book, Arendt began arranging for its publication in English. See: Arendt and Jaspers (1992, pp. 51-6, 603); Young-Bruehl (1982, pp. 62 ff., 213-9); Barnouw (1990, pp. 158 ff.); and Rabinbach (1996, pp. 15-17).

4 Young-Bruehl (1982, p. 216) suggests Arendt and her husband Heinrich Blücher were concerned that Jaspers' text was 'not political enough'. These concerns are reflected in a letter to Jaspers in which Arendt wonders whether the solidarity on which metaphysical guilt is predicated should be widened to encompass the less 'absolute' and more worldly solidarity that ought to exist among citizens of a republic (Arendt and Jaspers, 1992, p. 54).

5 In fact, this sentiment might more appropriately be described as shame. Indeed, shame is sometimes contrasted against guilt as the proper affective response to wrongs perpetrated by fellow group members (e.g. Ignatieff, 1996, p. 117; Gaita, 2000, pp. 282ff.). Unlike guilt, the sentiment of shame 
does not presuppose direct wrongdoing but rather a communal liability or 'moral taint'. However, from an Arendtian perspective, shame is as unworldly as guilt since: i) it is predicated on a non-political form of organization, i.e. the 'nation as family'; and ii) its proper expression entails a withdrawal from the public sphere, for the self that is ashamed wants to hide itself from others.

6 Arendt (1987, p. 43) is similarly dismayed by those 'good white liberals' in the United States who 'confess to guilt feelings with respect to the Negro question' (see also CR, p. 162).

7 Arendt's idea of 'morality' here is too reductive. While she claims to distinguish the 'political' from the 'moral', in fact she distinguishes between two kinds of morality: public and private.

8 So, for instance, a new regime has an obligation to institute mechanisms of transitional justice, which will probably include prosecutions, reparations and some kind of truth commission; e.g. the ANC government in South Africa had to assume responsibility for state wrongs perpetrated by the apartheid regime.

References

Arendt, H. (1950) 'The aftermath of Nazi rule: report from Germany',

Commentary, October, pp. 342-53.

Arendt, H. (1958) The Origins of Totalitarianism, 2nd edition. London: Allen

\& Unwin.

Arendt, H. (1964) 'Personal responsibility under dictatorship', The Listener, 6

August, 185-7, 205.

Arendt, H. (1968) Men in Dark Times. London: Harcourt Brace \& Co.

Arendt, H. (1970) Crises of the Republic. London: Harcourt Brace Jovanovich.

Arendt, H. (1971a) 'Thinking and moral considerations: a lecture', Social

Research, 38, 417-46.

Arendt, H. (1971b) 'On Responsibility for Evil', in R. A. Falk, G. Kolko and R.

J. Lifton (eds), Crimes of War. New York NY: Random House.

Arendt, H. (1977) Eichmann in Jerusalem: a Report on the Banality of Evil.

New York NY: Penguin Books.

Arendt, H. (1977) Between Past and Future: Eight Exercises in Political

Thought. Harmondsworth: Penguin.

Arendt, H. (1978) 'Organised Guilt and Universal Responsibility' and

'Eichmann in Jerusalem: an Exchange of Letters between Gershom Scholem

and Hannah Arendt', in R. H. Feldman (ed.), The Jew as Pariah: Jewish Identity and Politics in the Modern Age. New York NY: Grove Press.

Arendt, H. (1987) 'Collective Responsibility', in J. Bernauer (ed.), Amor

Mundi: Explorations in the Faith and Thought of Hannah Arendt. Dordrecht:

Martinus Nijhoff.

Arendt, H. (1990) On Revolution. Harmondsworth: Penguin.

Arendt, H. (1994) 'Approaches to the "German problem", and

'Understanding and politics', in Jerome

Kohn (ed.), Essays in Understanding 1930-1954. New York NY: Harcourt

Brace \& Co.

Arendt, H. (1998) The Human Condition 2nd edition. Chicago IL: University

of Chicago Press.

Arendt, H. and Jaspers, K. (1992) Hannah Arendt-Karl Jaspers Correspondence

1926-1969. L. Kohler and H. Saner (eds). New York NY: Harcourt Brace

Jovanovich.

Barnouw, D. (1990) Visible Spaces: Hannah Arendt and the German-Jewish

Experience. Baltimore MD: Johns Hopkins University Press. 
Bhargava, R. (2000) 'The moral justification of truth commissions', in C. VillaVicencio and W. Verwoerd (eds), Looking Back, Reaching Forward: Reflections on the Truth and Reconciliation Commission of South Africa. London: Zed Books.

Brooks, R. (ed.) (1999) When Sorry isn't Enough: the Controversy over Apologies and Reparations for Human Injustice. London: Longman.

Buruma, I. (1995) Wages of Guilt: Memories of War in Germany and Japan. London: Random House.

Canovan, M. (1992) Hannah Arendt: a Reinterpretation of Her Political Thought. Cambridge: Cambridge University Press.

Christodoulidis, E. (2000) " "Truth and reconciliation" as risks', Social and Legal Studies. 9 (2), 179-204.

Crocker, D. (1999) 'Reckoning with past wrongs: a normative framework', Ethics and International Affairs, 13, 43-64.

Duvenage, P. (1999) 'The politics of memory and forgetting after Auschwitz and apartheid', Philosophy and Social Criticism, 25 (3), 1-28.

Gaita, R. (2000) 'Guilt, Shame and Collective Responsibility', in M. Grattan (ed.), Reconciliation: Essays on Australian Reconciliation. Melbourne: Black Inc.

Habermas, J. and Michnik, A. (1994) 'Overcoming the past', New Left Review, 203, 3-16.

Howard, J. (2000) 'Practical Reconciliation', in M. Grattan (ed.),

Reconciliation: Essays on Australian

Reconciliation. Melbourne: Black Inc. Humphrey, M. (2000) 'From terror to trauma: commissioning truth for national reconciliation', Social Identities, 6 (1), 7-27.

Ignatieff, M. (1996) 'Articles of faith', Index on Censorship, 25 (5) 110-22. Jaspers, K. (1961) The Question of German Guilt. New York NY: Capricorn Books.

Kateb, G. (1984) Hannah Arendt: Politics, Conscience, Evil. Oxford: Martin Robertson.

Kritz, N. (ed.) (1995) Transitional Justice: How Emerging Democracies Reckon with Former Regimes. Volume I:

General Considerations. Washington DC: United States Institute of Peace Press. Krog, A. (1998) Country of My Skull. Johannesburg: Random House South Africa.

Moon, C. (2000) 'Prelapsarian State: the Metaphor of Reconciliation in South Africa', Paper presented at Political Studies Association conference, London School of Economics, 10-15 April. Morris, H. (1976) On Guilt and Innocence: Essays in Legal Philosophy and Moral Psychology. Berkeley CA: University of California Press.

Norval, A. (1999) 'Truth and reconciliation: the birth of the present and the reworking of history', Journal of Southern African Studies, 25 (3), 499-519. Olick, J. and Daniel, L. (1997) 'Collective memory and cultural constraint: holocaust myth and rationality in German politics', American Sociological Review, 62, 921-36.

Rabinbach, A. and Zipes, J. (eds) (1986) Germans and Jews since the Holocaust: the Changing Situation in West Germany. New York: Holmes \& Meier.

Rabinbach, A. (1996) 'The German as pariah: Karl Jaspers and the question of German guilt', Radical Philosophy, 75, 15-25.

Reuter, L. (1990) 'Political and Moral Culture in West Germany: Four Decades of Democratic Reorganisation and Vergangenheitsauseinandersetzung', in K. Harms, L. R. Reuter and V. Dùrr (eds), Coping with the Past: Germany and Austria after 1945. Madison WI: University of Wisconsin Press. Schwan, G. (1998) 'Political consequences of shared guilt', Constellations 5 (4) 472-91. 
Villa, D. (1995) Arendt and Heidegger: the Fate of the Political. Princeton NJ: Princeton University Press.

Villa, D. (1999) Philosophy, Politics, Terror: Essays on the Thought of Hannah Arendt. Princeton NJ: Princeton University Press.

Villa-Vicencio, C. (1996) 'On Taking Responsibility', in H. R. Botman and R.

M. Peterson (eds), To Remember and to Heal. Cape Town: Human \& Rousseau.

Villa-Vicencio, C. (2000) 'Restorative Justice: Dealing with the Past

Differently', in C. Villa-Vicencio and W. Verwoerd (eds), Looking Back,

Reaching Forward: Reflections on the Truth and Reconciliation Commission of South Africa. London: Zed Books.

Williams, G. (1998) 'Love and responsibility: a political ethic for Hannah

Arendt', Political Studies 46 (5) 937-50.

Young-Bruehl, E. (1982) Hannah Arendt: for Love of the World. New Haven

CT: Yale University Press.

Zalaquett, J. (1995) Untitled conference presentation, in A. Boraine and J. Levy (eds), The Healing of a Nation? Capetown: Justice in Transition. 


\section{University Library}

\section{- M M N E R VA A gateway to Melbourne's research publications}

Minerva Access is the Institutional Repository of The University of Melbourne

Author/s:

Schaap, Andrew

Title:

Guilty subjects and political responsibility: Arendt, Jaspers and the resonance of the German question in politics of reconciliation

Date:

2001-09

Citation:

Schaap, A. (2001). Guilty subjects and political responsibility: Arendt, Jaspers and the resonance of the German question in politics of reconciliation. Political Studies, 49(4), 749-766.

Publication Status:

Published

Persistent Link:

http://hdl.handle.net/11343/34367 